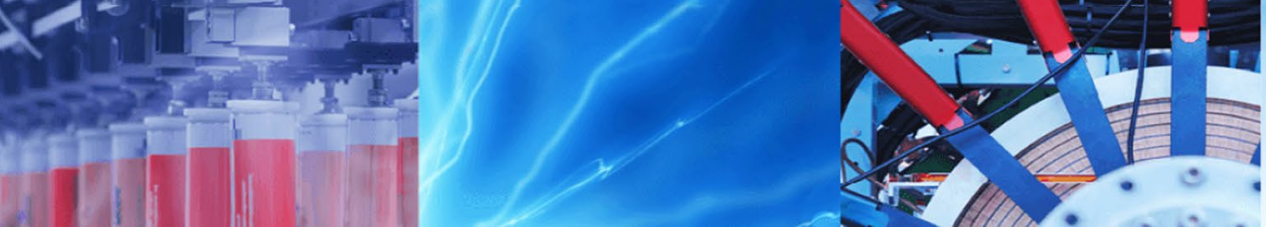

Short Communication

\title{
The potential of thermal power plant fly ash to promote the growth of Indian mustard (Brassica juncea) in agricultural soils
}

\author{
Adnan Shakeel ${ }^{1} \cdot$ Abrar Ahmad Khan $^{1} \cdot$ Gufran Ahmad $^{1}$
}

(c) Springer Nature Switzerland AG 2019

\begin{abstract}
The disposal of fly ash from thermal power plants causes significant economic and environmental problems. Although the fly ash contains several essential minerals, its application in agricultural practices is uncommon in India. The present study was undertaken to elucidate the possibility of fly ash application to agricultural soils to improve growth and yield in Indian mustard. This work was conducted to evaluate the effect of fly ash on growth, yield and chlorophyll content of the Indian mustard (Brassica juncea L.cv. Varuna). For that, a greenhouse experiment was conducted to observe the effect of various fly ash concentrations $(0 \%, 10 \%, 20 \%, 30 \%, 40 \%$ and $50 \% \mathrm{w} / \mathrm{w})$ with normal field soil on plant growth, yield and photosynthetic pigments. The plant growth (length, fresh weight and dry weight of shoot and root; number of leaves and branches per plant), yield (number of pods per plant, number of seeds per pod and weight of 100 seeds per plant) and pigment content (chlorophyll 'a', chlorophyll 'b' and total chlorophyll) parameters were found to be significantly increased from 10 to $30 \%$ fly ash levels being maximum at 30\%. However, at higher levels $40 \%$ to $50 \%$ of fly ash, growth, yield and pigment content parameters were reduced significantly. The perusal of the data revealed that $30 \%$ level of fly ash amendment in soil was found to be ideal for better growth, yield and pigment content of Indian mustard.
\end{abstract}

Keywords Chlorophyll · Concentration · Fly ash · Growth · Mustard · Yield

\section{Introduction}

Environmental pollution is one of the major problems that are threatening the stability of life on earth. The economic development of many countries is still directly proportional to their power generation capacity through coal burning. The air pollution caused by coal-fired thermal power plants affects soil, water, vegetation, whole ecosystem and human health [5]. Fly ash (FA) is a particulate air pollutant which is produced as a waste product of coal burning in thermal power plants. The current rate of FA generation in India is about 131.09 MT, of which 73.13 MT is utilized per year [19]. Because of the generation of FA in large quantities, there is a need of a sustainable method for its utilization and remediation. Fly ash can be utilized for economic profit in an environmentally friendly manner rather than dumping it [14]. Only $1.93 \%$ of the FA is utilized for agriculture [3]. It can be used in agriculture as a source of nutrients, or additives to soils to improve the properties as it contains essential plant nutrients $[17,22]$. The amount of nitrogen present in fly ash is considered as insignificant [25].

Fly ash amendment to soil enhances soil characteristics such as $\mathrm{pH}$ (Table 1), water holding capacity, bulk density and porosity [16]. It has also shown great promise as an amendment in phytoremediation of metal-polluted soils [24]. Fly ash-treated soil has been reported with higher number of bacteria and improved activity of enzymes such as urease, alkaline phosphatase and dehydrogenase which are beneficial for plant growth [26]. So far, FA has been tested to improve plant growth and yield in a number of plants such as Triticum aestivum, Cicer arietinum, Lens

$\triangle$ Adnan Shakeel, adnanshakeel1717@gmail.com | 1 Section of Environmental Botany, Department of Botany, Aligarh Muslim University, Aligarh 202002, India.

SN Applied Sciences (2019) 1:375 | https://doi.org/10.1007/s42452-019-0404-9

Received: 7 December 2018 / Accepted: 23 March 2019 / Published online: 28 March 2019 
Table 1 Chemical characteristics of soil before sowing and of fly ash before mixing in soil

\begin{tabular}{|c|c|c|c|}
\hline $\begin{array}{l}\text { Characteristics } \\
\text { Texture }\end{array}$ & $\begin{array}{l}\text { Soil (T1) } \\
\text { Sandy loam }\end{array}$ & $\begin{array}{l}\text { Fly ash } \\
\text { Silty }\end{array}$ & $30 \%$ fly ash (T4) \\
\hline p.H & $7.8^{\mathrm{b}} \pm 0.2$ & $8.5^{c} \pm 0.15$ & $8.31^{\mathrm{a}} \pm 0.74$ \\
\hline Organic carbon (\%) & $0.566^{\mathrm{b}} \pm 0.07$ & $0.202^{C} \pm 0.027$ & $1.27^{\mathrm{a}} \pm 0.12$ \\
\hline $\mathrm{NO}_{3^{-}}-\left(\mathrm{g} \mathrm{kg}^{-1}\right.$ soil $)$ & $0.262^{b} \pm 0.015$ & $0.063^{c} \pm 0.005$ & $0.289^{\mathrm{a}} \pm 0.02$ \\
\hline Phosphorous ( $\mathrm{g} \mathrm{kg}^{-1}$ soil) & $0.142^{b} \pm 0.010$ & $0.03^{c} \pm 0.015$ & $0.168^{\mathrm{a}} \pm 0.01$ \\
\hline Potassium $\left(\mathrm{mg} \mathrm{l}^{-1}\right)$ & $20.4^{b} \pm 1.06$ & $15.0^{C} \pm 0.55$ & $35.2^{\mathrm{a}} \pm 3.6$ \\
\hline Magnesium (mg l-1) & $31.4^{b} \pm 1.02$ & $18.5^{c} \pm 0.56$ & $42.3^{\mathrm{a}} \pm 3.7$ \\
\hline Calcium (mg I ${ }^{-1}$ ) & $18.5^{b} \pm 0.95$ & $19.7^{b} \pm 0.46$ & $33.2^{\mathrm{a}} \pm 2.9$ \\
\hline Sodium (mg l-1) & $11.6^{c} \pm 0.43$ & $16.0^{b} \pm 0.58$ & $20.3^{\mathrm{a}} \pm 1.7$ \\
\hline Carbonate $\left(\mathrm{mg} \mathrm{l}^{-1}\right)$ & $77.6^{\mathrm{b}} \pm 0.96$ & $69.5^{c} \pm 1.04$ & $98.5^{\mathrm{a}} \pm 7.9$ \\
\hline Bicarbonate $\left(\mathrm{mg} \mathrm{l}^{-1}\right)$ & $18.5^{\mathrm{b}} \pm 0.40$ & $13.3^{c} \pm 0.47$ & $34.2^{\mathrm{a}} \pm 3.1$ \\
\hline Sulphate $\left(\mathrm{mg} \mathrm{I}^{-1}\right)$ & $16.5^{c} \pm 0.40$ & $25.4^{\mathrm{b}} \pm 1.23$ & $36.4^{\mathrm{a}} \pm 3.43$ \\
\hline Chloride $\left(\mathrm{mg} \mathrm{l}^{-1}\right)$ & $25.4^{\mathrm{b}} \pm 1.22$ & $18.5^{\mathrm{c}} \pm 0.35$ & $38.6^{\mathrm{a}} \pm 3.67$ \\
\hline Nickel (mg kg ${ }^{-1}$ soil) & $12.1^{c} \pm 0.30$ & $193.3^{\mathrm{a}} \pm 2.28$ & $24.2^{\mathrm{b}} \pm 0.90$ \\
\hline Cadmium (mg kg ${ }^{-1}$ soil) & $0.008^{c} \pm 0.001$ & $0.9^{\mathrm{a}} \pm 0.11$ & $0.172^{\mathrm{b}} \pm 0.007$ \\
\hline
\end{tabular}

All determinations in $\mathrm{mg} \mathrm{I}^{-1}$ 1:5 (soil/fly ash: water extract), except $\mathrm{pH}$ or as specified

Each value is a mean of three replicates \pm standard deviation (SD)

Different letters indicate significant between treatments culinaris, Cynodon dactylon, Mentha citrate, Pisum sativum, Solanum melongena, Allium cepa, Saccharum officinarum, Solanum tuberosum.

Indian mustard ( $B$. juncea $L$.) is an annual herbaceous plant and belongs to the family Brassicaceae of angiosperms. The crop matures within 105-160 days and has a yield potential of $1500-3000 \mathrm{~kg} / \mathrm{ha}$. It is an important oil seed crop with a global oil production of 12-14 Mt. It is the third most important source of vegetable oil in the world after soybean (Glycine max) and palm (Elaeis guineensis Jacq.) [18]. Besides its use as an edible oil, it has a great medicinal importance. Its oil contains many fatty acids of which erucic and linoleic acids are very important. They provide the most concentrated source of energy and also help in absorption of assured vitamins such as A, D, E and K. Residual part of seeds is used as cattle feed and as fertilizer. The $B$. juncea commonly called Lahi is predominantly cultivated in Rajasthan, Uttar Pradesh and other adjoining states of India as an oil crop. Indian mustard also presents great potential for phytoremediation [2]. Keeping in mind the economic importance and remediation property of Indian mustard, it was planned to evaluate the response of $B$. juncea $\mathrm{cv}$. Varuna to FA.

\section{Materials and methods}

A pot experiment was conducted with Brassica juncea L.cv. Varuna under greenhouse conditions at Department of Botany, Aligarh Muslim University, India. An average day/night temperature of $25^{\circ} \mathrm{C} / 18^{\circ} \mathrm{C}\left( \pm 3^{\circ} \mathrm{C}\right)$ with relative humidity of $70 \pm 5 \%$ was maintained during the experiment with a photoperiod of 16:8 light and dark. The FA used for the experimental work was collected in gunny bags from Thermal Power Plant, Kasimpur, Aligarh, India. The physical and chemical properties of fly ash and test soil were determined by following standard protocols (Table 1). Soil from agricultural field was collected and mixed with FA in different concentrations and autoclaved at $20 \mathrm{lb}$ pressure for $20 \mathrm{~min}$. The treatments were formulated as:

T1 $1000 \mathrm{~g}$ field soil + nil FA (control).

T2 $900 \mathrm{~g}$ field soil $+100 \mathrm{~g} \mathrm{FA} \mathrm{(10 \%} \mathrm{fly} \mathrm{ash} \mathrm{in} \mathrm{soil).}$

T3 $800 \mathrm{~g}$ field soil $+200 \mathrm{~g} \mathrm{FA} \mathrm{(20 \%} \mathrm{fly} \mathrm{ash} \mathrm{in} \mathrm{soil).}$

T4 $700 \mathrm{~g}$ field soil $+300 \mathrm{~g} \mathrm{FA} \mathrm{(30 \%} \mathrm{fly} \mathrm{ash} \mathrm{in} \mathrm{soil).}$

T5 $600 \mathrm{~g}$ field soil $+400 \mathrm{~g} \mathrm{FA}$ ( $40 \%$ fly ash in soil).

T6 $500 \mathrm{~g}$ field soil $+500 \mathrm{~g} \mathrm{FA} \mathrm{(50 \%} \mathrm{fly} \mathrm{ash} \mathrm{in} \mathrm{soil).}$

After properly mixing the soil with FA, five pots of $6 \mathrm{~cm}$ height were filled with $1 \mathrm{~kg}$ of each type of mixture. Thus, for each treatment, five replicates were made. In total, 30 pots ( 6 treatments $\times 5$ replicates) were prepared for the experiment. Ten seeds were sown in each type of soil-FA mixture. 2 weeks after the germination of seeds, thinning of seedlings was done to maintain one healthy plant in each pot. Pots were irrigated twice in a week with required amount of water. Estimation of chlorophyll content was done at 75 DAS (days after sowing), whereas yield parameters were recorded at 120 DAS. Leaves and branches were observed at pre-flowering stage. 


\subsection{Chlorophyll estimation}

Chlorophyll ( $a$ and $b$ ) was estimated according to the method of Arnon (1949). Fresh mustard leaves plucked 1 week before termination of the experiment, from the same position (top fourth leaf) of plant in all treatments were weighed $(100 \mathrm{~g})$ and macerated in $80 \%$ acetone with the help of a mortar and pestle. The suspension was filtered through the Whatman filter paper No. 1. The filtrate was collected and adjusted to a known volume. The absorbance was read at 663 and $645 \mathrm{~nm}$ against $80 \%$ acetone blank on a spectrophotometer. The chlorophyll a, chlorophyll b and total chlorophyll present in the given extract were calculated according to following formulae:

(a) $\mathrm{mg}$ chlorophyll a/g fresh leaf $=12.7$ (663 O.D) -2.69 (645 O.D) $\times \frac{v}{w \times 1000}$.

(b) $\mathrm{mg}$ chlorophyll b/g fresh leaf $=22.9(645$ O.D) -4.68 (663 O.D) $\times \frac{v}{W \times 1000}$.

O.D = Optical density (absorbance); $V=$ Volume; $W=$ Weight of leaf.

\subsection{Statistical analysis}

Data are presented as mean $(n=5) \pm$ standard deviation (SD). Different letters indicate significant differences between treatments, $p<0.05$, $(n=5)$. In order to determine the significance at $p<0.05$ of the given data, analysis of variance (ANOVA) with LSD post hoc tests were used to determine significant differences by using SPSS version 17.0 software.

\section{Results and discussion}

\subsection{Growth}

The growth of $B$. Juncea was observed in different concentrations of FA amended with soil. Data present in Table 2 show that growth of the plant was significantly influenced to FA concentrations as compared to control. The result indicated that with increase in FA concentration up to $30 \%$, the plant showed increase in growth. The best values of growth parameters (shoot length $119.4 \mathrm{~cm}$ and root length $19.6 \mathrm{~cm}$; fresh and dry weight of shoot $98.0 \mathrm{~g}$ and $24.6 \mathrm{~g}$; fresh and dry weight of root $23.2 \mathrm{~g}$ and $7.0 \mathrm{~g}$; number of leaves 42.5 and branches per plant 17) were recorded in $\mathrm{T} 4$ (30\% FA). With further increase in FA levels, reduction in the growth of the plant was observed. The lowest values of growth parameters (shoot length $95.0 \mathrm{~cm}$, root length $14.0 \mathrm{~cm}$; fresh and dry weight of shoot $47.0 \mathrm{~g}$ and $11.83 \mathrm{~g}$; fresh and dry weight of root 16.4 and 4.1; and number of leaves 23 and branches 9.0 per plant) were found in T6 (50\% FA).

\subsection{Yield}

The yield of $B$. juncea was observed in different concentrations $(0,10,20,30,40$ and $50 \%)$ of FA. The data present in Table 3 show that with increase in FA levels up to $30 \%$, the yield was increased. The highest values of yield parameters (No. of pods/plant 46.4, No. of seeds/pod 12.4 and weight of 100 seeds $0.55 \mathrm{~g}$ ) were recorded in T4 (30\% FA level). With further increase in the concentration of $F A$, the plants showed reduction in yield. The lowest value of yield parameters (No. of pods/plant 33.6, No. of seeds/plant 9.8 and weight of 100 seeds 0.39 ) was recorded in T6 (50\% FA).

Table 2 Effect of fly ash amendment to soil on plant growth of $B$. juncea

\begin{tabular}{|c|c|c|c|c|c|c|c|c|}
\hline \multirow[t]{2}{*}{ FA (\%) } & \multicolumn{2}{|l|}{ Length (cm) } & \multicolumn{2}{|l|}{ Fresh wt.(g) } & \multicolumn{2}{|l|}{ Dry wt. (g) } & \multirow[t]{2}{*}{ Leaves/plant } & \multirow[t]{2}{*}{ Branches/per plant } \\
\hline & Shoot & Root & Shoot & Root & Shoot & Root & & \\
\hline Control & $99.4^{\mathrm{ab}} \pm 0.44$ & $15.0^{b c} \pm 0.83$ & $56.0^{d} \pm 0.54$ & $20.0^{\mathrm{b}} \pm 0.36$ & $13.5^{\mathrm{de}} \pm 0.98$ & $5.4^{b} \pm 0.27$ & $27.5^{\mathrm{b}} \pm 0.83$ & $13.0^{c} \pm 0.54$ \\
\hline 10 & $104.4^{\mathrm{ab}} \pm 0.53$ & $17.0^{\mathrm{ab}} \pm 0.70$ & $66.0^{c} \pm 0.70$ & $20.4^{b} \pm 0.28$ & $15.3^{c} \pm 0.32$ & $5.5^{\mathrm{ab}} \pm 0.21$ & $28.0^{d} \pm 0.54$ & $14.0^{b c} \pm 0.83$ \\
\hline 20 & $110.6^{b} \pm 0.94$ & $18.2^{\mathrm{ab}} \pm 1.22$ & $83.0^{\mathrm{b}} \pm 1.09$ & $22 .^{0 \mathrm{ab}} \pm 0.97$ & $20.8^{\mathrm{b}} \pm 1.09$ & $6.4^{\mathrm{ab}} \pm 0.63$ & $31.5^{c} \pm 1.48$ & $15.0^{\mathrm{b}} \pm 1.58$ \\
\hline 30 & $119.4^{\mathrm{a}} \pm 1.22$ & $19.6^{\mathrm{a}} \pm 1.90$ & $98.0^{\mathrm{a}} \pm 0.45$ & $23.2^{\mathrm{a}} \pm 1.03$ & $24.6^{a} \pm 0.57$ & $7.0^{\mathrm{a}} \pm 1.32$ & $42.5^{a} \pm 1.34$ & $17.0^{\mathrm{a}} \pm 1.08$ \\
\hline 40 & $96.8^{\mathrm{ab}} \pm 0.43$ & $14.8^{d} \pm 0.76$ & $52.0^{d} \pm 0.54$ & $18.2^{c} \pm 0.67$ & $13.7^{\mathrm{cd}} \pm 0.34$ & $5.2^{b} \pm 0.50$ & $26.0^{d} \pm 0.70$ & $11.0^{\mathrm{d}} \pm 0.54$ \\
\hline 50 & $95.0^{c} \pm 0.42$ & $14.0^{\mathrm{cd}} \pm 1.57$ & $47.0^{\mathrm{e}} \pm 0.43$ & $16.4^{d} \pm 1.09$ & $11.8^{\mathrm{e}} \pm 0.44$ & $4.1^{c} \pm 0.76$ & $23.0^{\mathrm{e}} \pm 0.89$ & $9.0^{\mathrm{e}} \pm 0.83$ \\
\hline LSD at $5 \%$ & 8.24 & 1.13 & 6.87 & 1.93 & 1.42 & 0.37 & 1.46 & 1.18 \\
\hline
\end{tabular}

Each value is a mean of five replicates \pm standard deviation (SD)

Different letters indicate significant between treatments 
Table 3 Effect of fly ash amendment to soil on yield and chlorophyll content of B. juncea

\begin{tabular}{|c|c|c|c|c|c|c|}
\hline FA (\%) & Pods/plant & Seeds/pod & 100 seed wt./plant & chl. (a) & chl. (b) & Total chl. \\
\hline Control & $38.0^{c} \pm 0.83$ & $11.2^{\mathrm{bcd}} \pm 0.87$ & $0.48^{b} \pm 0.48$ & $0.713^{b} \pm 0.08$ & $0.336^{b} \pm 0.10$ & $1.049^{\mathrm{b}} \pm 0.12$ \\
\hline 10 & $41.0^{c} \pm 1.50$ & $11.4^{\mathrm{abc}} \pm 0.54$ & $0.49^{b} \pm 0.29$ & $0.815^{b} \pm 0.10$ & $0.371^{\mathrm{ab}} \pm 0.80$ & $1.186^{\mathrm{ab}} \pm 0.68$ \\
\hline 20 & $44.0^{b} \pm 0.83$ & $11.8^{\mathrm{ab}} \pm 1.92$ & $0.52^{\mathrm{ab}} \pm 0.20$ & $0.845^{\mathrm{ab}} \pm 0.11$ & $0.455^{\mathrm{ab}} \pm 0.82$ & $1.320^{\mathrm{ab}} \pm 0.66$ \\
\hline 30 & $46.4^{\mathrm{a}} \pm 1.58$ & $12.4^{\mathrm{a}} \pm 1.14$ & $0.55^{\mathrm{a}} \pm 0.98$ & $0.931^{\mathrm{a}} \pm 0.34$ & $0.521^{\mathrm{a}} \pm 0.98$ & $1.452^{\mathrm{a}} \pm 0.76$ \\
\hline 40 & $37.0^{c} \pm 1.09$ & $10.2^{\mathrm{a}} \pm 1.14$ & $0.47^{b} \pm 0.30$ & $0.652^{b c} \pm 0.12$ & $0.274^{b c} \pm 0.10$ & $0.926^{b c} \pm 0.13$ \\
\hline 50 & $33.6^{d} \pm 1.02$ & $9.8^{d} \pm 1.02$ & $0.39^{c} \pm 0.40$ & $0.633^{c} \pm 0.12$ & $0.222^{c} \pm 0.19$ & $0.858^{\mathrm{C}} \pm 0.20$ \\
\hline LSD at $5 \%$ & 1.49 & 0.49 & 0.060 & 0.016 & 0.013 & 0.066 \\
\hline
\end{tabular}

Chlorophyll is expressed in unit's $\mathrm{mg}^{-1} \mathrm{~g}$

Each value is a mean of five replicates \pm standard deviation (SD)

Different letters indicate significant between treatments

\subsection{Chlorophyll content}

Similarly, the pigment content of $B$. juncea was also influenced by the amendment of different concentrations ( 0 , $10,20,30,40$ and $50 \%$ ) of FA to soil. The data present in Table 3 show that the chlorophyll content of the plant showed an increase with increase in FA levels up to $30 \%$. The highest values of pigmentation parameters (chlorophyll (a) 0.931, chlorophyll (b) 0.521 and total chlorophyll content 1.452) were recorded in T4 (30\% FA). With further increase in the level of fly ash, the chlorophyll content of the plant was reduced. The lowest levels of pigment parameters (chlorophyll a 0.633 , chlorophyll b 0.222 and total chlorophyll 0.858) were recorded in T6 (50\% FA).

The present experiment was conducted to evaluate the effect of FA on growth, yield and chlorophyll content of the Indian mustard. The observations showed that with a gradual increase in the concentration of FA from 10 to $30 \%$, the growth, yield and chlorophyll content of the plant increased over control, being highest at 30\%, possibly because of the presence of essential plant nutrients such as $\mathrm{Ca}, \mathrm{K}, \mathrm{Mg}$, S (Table 1). In addition to nutrient enrichment $[10,20]$, it also modifies the physical and chemical characteristics of soil and most importantly it enhances the $\mathrm{pH}$ of the soil (Table 1). The $\mathrm{pH}$ enhancement facilitates the availability of $\mathrm{K}, \mathrm{Mg}, \mathrm{P}$ and $\mathrm{Ca}$ in soil [11]. Fly ash enriches the soil with $C$ a which acts as a secondary messenger, regulates cell division and helps in cell wall formation [12]. In addition to $\mathrm{Ca}$, FA also increases the $S$ content of soil that is required in large quantity for mustard plants [13]. Sulphur is required in Fe-S cluster formation of photosynthetic apparatus, sulphur-containing proteins such as methionine, electron transport and secondary metabolism [6]. The improvement in chlorophyll content could be due to the presence of Mg in FA, which is the main component of chlorophyll and is required for the structural integrity of chloroplast. The beneficial effect of FA at lower levels (10-30\%) has already been observed on many crops such as tomato [15], wheat [8], chickpea [9], potato [23], pumpkin [1].

However, with further increase in FA levels from 30 to $50 \%$, the growth, yield and chlorophyll content showed a decline as compared to control. The reduction might be due to the presence of some toxic heavy metals such as $\mathrm{Cd}$ and $\mathrm{Ni}$ (Table 1), which are harmful at higher levels to the growth and yield of Indian mustard. The higher levels of FA increase the availability of heavy metals that may evoke oxidative stress by generation of ROS [7]. The ROS promotes DNA damage, obstructs membrane functional integrity and disturbs protein activity [21]. The reduction in photosynthetic pigments is probably due the nutritional imbalance caused by FA because of low availability of $\mathrm{N}$ and $P$ and high availability of heavy metals [4]. Therefore, higher levels of FA adversely affect the growth, yield and pigment content of Indian mustard. Similar results have been observed on several crops such as wheat [8], potato [23] and pumpkin [1]. In the present study, the 30\% FA was found best which shows that available nutrients in FA are beneficial at certain levels for utilization of a specific plant species.

\section{Summary}

A pot experiment was conducted under greenhouse to observe the effect of various fly ash concentrations $(0 \%$, $10 \%, 20 \%, 30 \%, 40 \%$ and $50 \% \mathrm{w} / \mathrm{w}$ ) with normal field soil on plant growth, yield and photosynthetic pigments. The results of this work suggest that FA can be used to improve soil properties as it contains essential plant nutrients. Fly ash, being treated as a waste, can be utilized in an ecofriendly manner in agriculture. The results also suggest that FA improves growth, yield and pigment content in Indian mustard at lower concentrations (10\% to $30 \%$ FA). But at higher concentrations (more than 30\% FA), it results in reduction in all the above-given parameters. These 
reductions in given parameters can be attributed to the heavy metals present in FA. As we increase the concentration of FA, the heavy metals present in it also increase.

Acknowledgements This study has not received financial support, and no competing financial interest exists for any of the authors. Authors would like to acknowledge the Department of Botany, Aligarh Muslim University, India, for kind assistance and laboratory facility.

\section{Compliance with ethical standards}

Conflict of interest The authors declare that they have no conflict of interest.

\section{References}

1. Ahmad G, Khan AA, Ansari S (2017) Interaction of a fly ash and root-knot nematode pathogens on Pumpkin (Cucurbita moschata Duch. ex Lam.). Trop Plant Res 4(3):449-455

2. Basharat Z, Novo L, Yasmin A (2018) Genome editing weds CRISPR: what is in it for phytoremediation? Plants 7(3):51. https ://doi.org/10.3390/plants7030051

3. CEA (2014-2015). Report on fly ash generation at coal/lignite based thermal power stations and its utilization in the country for the year 2014-2015. Central Electricity Authority, New Delhi

4. Dwivedi S, Tripathi RD, Srivastava S, Mishra S, Shukla MK, Tiwari KK, Singh R, Rai UN (2007) Growth performance and biochemical responses of three rice (Oryza sativa L.) cultivars grown in fly-ash amended soil. Chemosphere 67:140-151

5. Gur F, Yaprak G (2010) Natural radionuclide emission from coalfired power plants in south western of Turkey and the population exposure to external radiation in their vicinity. J Environ Sci Health A 45(14):1900-1908

6. Hell R, Hillebrand $H$ (2001) Plant concepts for mineral acquisition and allocation. Curr Opin Biotechnol 12:161-168

7. Hossain MA, Hasanuzzaman M, Fujita M (2010) Upregulation of antioxidant and glyoxalase systems by exogenous glycine betaine and proline in mung bean confer tolerance to cadmium stress. Physiol Mol Biol Plant 16:259-272

8. Kausar S (2007) Studies on the effect of air pollutants and seed gall nematode Anguinaltritici on wheat. Ph.D. Thesis, A.M.U. Aligarh, India

9. Khan AA, Saboor I (2014) Impact of coal-ash amended Soil on growth, yield and photosynthetic pigments of Cicer arietinum. J Funct Environ Bot 4(2):92-95

10. Kishor P, Ghosh AK, Kumar D (2010) Use of fly ash in agriculture: a way to improve soil fertility and its productivity. Asian J Agric Sci 4(1):1-14

11. Koo BG (2000) Effects of fly ash and gypsum application on soil improvement and rice cultivation. Ph.D. dissertation, Gyeongsang National University
12. Marschner $P$ (2012) Mineral nutrition of higher plants, 3rd edn. Academic Press, London

13. McGrath SP, Zhao FJ (1996) Sulphur uptake, yield responses and the interactions between nitrogen and sulphur in winter oilseed rape (Brassica napus). J Agric Sci 126:53-62

14. Mohan SKR, Jayabalan KP, Rajaraman A (2012) Properties of fly ash-based coconut fibre composite. Am J Eng Appl Sci 5:29-34

15. Raghav D, Khan AA (2002) Impact of industrial particulate pollutants applied to soil on growth and yield of tomato. J Agric Sci 35:187-194

16. Raj S, Mohan S (2014) Approach for improved plant growth using fly ash amended soil. Int J Emerg Technol Adv Res 4(6):709-715

17. Saarsalmi A, Smolander A, Kukkola M, Moilanen M, Saramaki $J$ (2012) 30-Year effects of wood ash and nitrogen fertilization on soil chemical properties, soil microbial processes and stand growth in a Scots pine stand. For Ecol Manag 278:63-70

18. Shekhawat K, Rathore SS, Premi OP, Kandpal BK, Chauhan JS (2012) Advances in agronomic management of Indian Mustard (Brassica juncea L. Czern j. Cosson): an overview. Int J Agron 1:1-14. https://doi.org/10.1155/2012/408284

19. Singh RK, Gupta NC (2014) Value added utilization of fly ashprospective and sustainable solutions. Int J Appl Sci Eng Res $3(1): 1-16$

20. Swamy TN, Dash N, Nahak G, Deo B, Sahu RK (2010) Effect of coal fly ash on growth, biochemistry, cytology and heavy metal content of Allium cepa L. NY Sci J 3(5):10-16

21. Tamás MJ, Sharma SK, Ibstedt S, Jacobson T, Christen P (2014) Heavy metals and metalloids as a cause for protein misfolding and aggregation. Biomolecules 4:252-267

22. Thind HS, Sharma S, Vashistha M, Singh G (2012) Land application of rice husk bagasse ash and coal fly ash: effects on crop productivity and nutrient uptake in rice-wheat system on alkaline loamy sand. Field Crop Res 135:137-144

23. Tomar D, Khan AA (2015) Physico-chemical properties of fly ash amended soils and their impact on potato crop. J Funct Environ Bot 5(2):87-95

24. Wiszniewska A, Hanus-Fajerska E, Muszynska E, Ciarkowska K (2016) Natural organic amendments for improved phytoremediation of polluted soils: a review of recent progress. Pedosphere 26(1):1-2

25. Yao ZT, Ji XS, Sarker PK, Tang JH, Ge LQ, Xia MS, Xia YO (2014) Comprehensive review on the application of coal fly ash. Earth Sci Rev 141:105-121

26. Yeledhalli NA, Prakash SS, Gurumurthy SB, Ravi MV (2010) Coal fly ash as modifier of physico-chemical and properties of soil. Karnataka J Agric Sci 20(3):1

Publisher's Note Springer Nature remains neutral with regard to jurisdictional claims in published maps and institutional affiliations. 